\title{
Studies on Physico-Chemical Composition of Aonla (Emblica officinalis G.) Fruit and Evaluation of Ginger Extract Concentration for Preparation of Aonla Candy cv. chakaiya
}

\author{
Gaurav Singh Vishen, Sanjay Pathak and Krishna Kumar Mishra* \\ Department of Post-Harvest Technology, N. D. U. A. \& T., Kumarganj, \\ Faizabad- 224229, Uttar Pradesh, India \\ *Corresponding author
}

\begin{tabular}{|c|c|}
\hline & A B S T R A C T \\
\hline & $\begin{array}{l}\text { The present investigation was executed at the Laboratory of Department of Post-Harvest } \\
\text { Technology. College of Horticulture and forestry, Narendra Deva University of }\end{array}$ \\
\hline Keywords & Agriculture \& Technology, Kumarganj, Faizabad (U.P.) India during in the year 2015-16. \\
\hline $\begin{array}{l}\text { Physico-chemical } \\
\text { composition, Anola, } \\
\text { Ginger extract. }\end{array}$ & $\begin{array}{l}\text { Experiment Physico-chemical composition of aonla fruit and evaluation of ginger extract } \\
\text { concentration for preparation of aonla candy was studied, and found that aonla fruit of cv. } \\
\text { Chakaiya had } 33.59 \mathrm{~g} \text { average fruit weight, } 8.80 \% \text { stone content, } 91.20 \% \text { pulp, } 3.19 \mathrm{~cm}\end{array}$ \\
\hline Article Info & $546.75 \mathrm{mg} / 100 \mathrm{~g}$ ascorbic acid, $2.60 \%$ reducing sugars, $2.23 \%$ non-reducing sugar, $4.83 \%$ \\
\hline $\begin{array}{l}\text { Accepted: } \\
\text { 26 September } 2017 \\
\text { Available Online: } \\
\text { 10 November } 2017\end{array}$ & $\begin{array}{l}\text { total sugars and } 160.56 \mathrm{mg} / 100 \mathrm{~g} \text { total phenols. Organoleptic evaluation was done to assess } \\
\text { the quality of aonla candy made from different concentration of ginger extract. The data on } \\
\text { overall ranking of sensory traits which were obtained by addition of score awarded to } \\
\text { different sensory traits reveal that treatment of ginger extract @ } 5 \% \text { in sucrose syrup was } \\
\text { rated like extremely with significantly higher points as compare to other treatments. }\end{array}$ \\
\hline
\end{tabular}

\section{Introduction}

Aonla (Emblica officinalis G.) commonly named as 'Indian gooseberry' belongs to family Euphorbiaceae, aonla is an important fruit crop of commercial significance. It is native to tropical regions of South-East Asia, particularly Central and Southern India. Aonla may be an important fruits of future due to its high medicinal and nutritional value. The aonla fruit is valued high among indigenous medicines in India. It is valued as an anti-ascorbutic, diuretic, laxative, antibiotic, acidic, cooling and refrigerant. Its fruit have excellent therapeutic value which is utilized for treatment of several diseases from ancient times like tuberculosis of lungs, asthma, bronchitis, scurvy, diabetes, anemia, weakness of memory, cancer, tension, influenza, cold, loss and grayness of hair etc. The richest source of vitamin $\mathrm{C}$ next to barbados cherry (300-900 mg/100g). Aonla candies have better self-life, an easy preparation technology with low preparation cost and good return, but have no aroma and attractive flavour. Ginger (Zingiber officinalis L.) is an indigenous plant belongs to family Zingiberaceae. It is valuable cash crop and important spice crop of world. Ginger is also an Ayurvedic crop and its test and flavour is 
very much acceptable to Indian peoples. It promotes cleaning of the body through perspiration to calm nausea, and to stimulate the appetite. The concentration of ginger extract is very much important for quality candy, which was not standardized.

\section{Materials and Methods}

In the present study, the Chakaiya cultivars of aonla fruit were taken in the $1^{\text {st }}$ week of January, 2016 from the main Experiment Station, Department of Horticulture, Narendra Deva University of Agriculture and Technology, Kumarganj, Faizabad (U.P.). The fruits were harvested from the trees by hands to avoid any type of physical damage including bruising. The fruits were transported from orchard to the post-harvest technology laboratory of Department of postharvest technology in the corrugated fiber board boxes.

Physico-chemical characteristics of aonla fruit was recorded on the following parameter

Fruit Weight (g), Fruit size (length \& width in $\mathrm{cm})$, Pulp Content (\%), Stone Content (\%), Fruit shape. Total soluble solids (\%), Acidity (\%), Vitamin C mg/100g pulp, Reducing sugars $(\%)$, Non Reducing Sugar (\%), Total sugars (\%), Total phenols (mg/100g Fruit pulp). The analysis of the physical and chemical characteristics of aonla fruit was ready at marketing stage.

\section{Evaluation of ginger concentration for preparation of aonla candy}

$3 \mathrm{~kg}$ of blemish free mature and uniform size of fresh fruits, for each treatment were taken and washed properly with fresh water. Thereafter, the fruits were blanched in boiling water with $2 \%$ alum for five minutes. After boiling the aonla fruits segments were separated by hand and washed 3 times with the fresh water. Prepare twenty seven liter sugar syrup containing $50 \%$ TSS were divided into nine equal volume in nine containers thereafter, added ginger extract in the volume of $\mathrm{T}_{0}$ : Control (not added), $\mathrm{T}_{1}$ : @ $1 \%$ ginger extract in sucrose syrup, $\mathrm{T}_{2}$ : @ 2\% ginger extract in sucrose syrup, $\mathrm{T}_{3}$ : @ 3\% ginger extract in sucrose syrup, $\mathrm{T}_{4}$ : @ 4\% ginger extract in sucrose syrup, $\mathrm{T}_{5}$ : @ 5\% ginger extract in sucrose syrup, $\mathrm{T}_{6}$ : @ 6\% ginger extract in sucrose syrup, $\mathrm{T}_{7}$ : @ 7\% ginger extract in sucrose syrup and $\mathrm{T}_{8}$ : @ 8\% ginger extract in sucrose syrup at slightly hot stage and mixed thoroughly. After blanching and washing of above fruit segments were steeped into nine above different containers containing sugar syrup of $50 \%$ TSS and ginger extract of different concentration for 24 hour. Then next day, segments were drained and concentration of syrup was maintained $60 \%$ by adding sugar and again segment of each treatment were steeped, after 24 hours concentration of the syrup was maintained $70 \%$ by above process and segment were left in it for 3 days. Thereafter, segments were drained and washed to remove adhering layer of sugar by 3-4 quick dips into hot water after putting into muslin cloth. These pieces were dried in the hot air oven at $50^{\circ} \mathrm{C}$ for 8-10 hours and the candies were evaluated by sensory test (Organoleptic rating) and the panel of 10 judges on the basis of 9 point hedonic scale.

\section{Methodology adopted in observation}

The Total Soluble Solids (\%), Acidity (\%), Browning (Non-enzymatic) and Ascorbic acid (mg/100gm) were determined by the method of Rangana, 2010, Standardization of Dye were determined by the method of Jonson, B.C., 1948, Sugars (\%) were determined by Saffer Somogyi Method, The total phenols and the organoleptic evaluation for accessing the taste, colour, flavour and texture of the 
samples, were conducted by panel of 10 judges who scored on a 9 point hedonic scale by (Amerine et al., 1965).

\section{Results and Discussion}

The data pertaining to the physical composition of aonla fruit are presented in table 1. Average fruit weight, stone percentage and pulp percentage were recorded $33.59 \mathrm{~g}, 8.80 \%$ and $91.20 \%$, while average length and width of fruit was found 3.19 and $4.19 \mathrm{~cm}$, respectively. Among the different factor influencing fruit quality, Physicochemical components in aonla fruit are of utmost concern to assess the fruit either for desert purposes or for fruit processing. Several scientists have reported Average fruit weight 32.45 to $53.40 \mathrm{~g}$ Pathak (1988), in Chakaiya and $35.70 \mathrm{~g}$ in Banarasi. Gehlat and Singh (2008). Stone and pulp percentage was observed in cv. Chakaiya, 8.80 and 91.20, respectively. Singh and Pathak (1987) reported 90.20 to 94.40 per cent edible part. Average fruit length and width were observed 3.19 and $4.19 \mathrm{~cm}$, respectively in aonla fruit. Several scientists have reported greater variability in average fruit length and width of aonla fruit ranged from $3.60 \mathrm{~cm}$ and $4.38 \mathrm{~cm}$ in NA-7 (A. I. C. R. P on Arid Zone fruits 2006), $3.27 \mathrm{~cm}$ and $4.00 \mathrm{~cm}$ in Chakaiya (Gehlat and Singh, 2008), $3.25 \mathrm{~cm}$ and 4.13 $\mathrm{cm}$ in Banarasi (Ahmad et al., 2010), and 3.45 $\mathrm{cm}$ and $3.75 \mathrm{~cm}$ in Kanchan (Mandal et al., 2011). Fruit shape was observed to be spherical in Chakaiya cultivar of aonla fruit.

The differences between physical characters in present findings and in reported literature may be attributed to differences in location, orchard management, climatic conditions, fruit maturity, age of tree and growing season. Data recorded on chemical composition of aonla fruit are presented in table 2 .

Table.1 Physical characteristics of aonla fruit

\begin{tabular}{|c|c|c|c|}
\hline S. No. & \multicolumn{2}{|c|}{ Characters } & Average value \\
\hline 1. & \multicolumn{2}{|c|}{ Fruit weight (g) } & 33.59 \\
\hline 2. & \multicolumn{2}{|l|}{ Stone $(\%)$} & 8.80 \\
\hline 3. & \multicolumn{2}{|l|}{ Pulp (\%) } & 91.20 \\
\hline \multirow{2}{*}{4.} & \multirow{2}{*}{ Fruit size } & Length $(\mathrm{cm})$ & 3.19 \\
\hline & & Width $(\mathrm{cm})$ & 4.19 \\
\hline 5. & \multicolumn{2}{|l|}{ Fruit shape } & Spherical \\
\hline
\end{tabular}

Table. 2 Chemical characteristics of aonla fruit

\begin{tabular}{|c|l|c|}
\hline S. No. & Characters & Average value \\
\hline $\mathbf{1 .}$ & TSS $(\%)$ & 10.00 \\
\hline $\mathbf{2 .}$ & Acidity $(\%)$ & 2.25 \\
\hline $\mathbf{3 .}$ & Ascorbic acid $(\mathrm{mg} / 100 \mathrm{~g})$ & 546.75 \\
\hline $\mathbf{4 .}$ & Reducing sugars $(\%)$ & 2.60 \\
\hline $\mathbf{5 .}$ & Non-reducing sugar $(\%)$ & 2.23 \\
\hline $\mathbf{6 .}$ & Total sugars $(\%)$ & 4.83 \\
\hline $\mathbf{7 .}$ & Total phenols $(\mathrm{mg} / 100 \mathrm{~g})$ & 160.56 \\
\hline
\end{tabular}


Table.3 Evaluation of different concentration of ginger extract on organoleptic quality of aonla candy

\begin{tabular}{|c|c|l|}
\hline \multicolumn{1}{|c|}{ Treatments } & Score & \multicolumn{1}{c|}{ Rating } \\
\hline $\mathrm{T}_{0}:$ Control (not added) & 6.50 & Like moderately (LM) \\
\hline $\mathrm{T}_{1}:$ @ 1\% ginger extract in sucrose syrup & 6.80 & Like moderately (LM) \\
\hline $\mathrm{T}_{2}:$ @ 2\% ginger extract in sucrose syrup & 7.00 & Like moderately (LM) \\
\hline $\mathrm{T}_{3}:$ @ 3\% ginger extract in sucrose syrup & 7.40 & Like very much (LVM) \\
\hline $\mathrm{T}_{4}:$ @ 4\% ginger extract in sucrose syrup & 7.95 & Like very much (LVM) \\
\hline $\mathrm{T}_{5}:$ @ 5\% ginger extract in sucrose syrup & 8.40 & Like extremely (LE) \\
\hline $\mathrm{T}_{6:}$ @ 6\% ginger extract in sucrose syrup & 7.85 & Like very much (LVM) \\
\hline $\mathrm{T}_{7}$ @ 7\% ginger extract in sucrose syrup & 7.60 & Like very much $(\mathrm{LVM})$ \\
\hline $\mathrm{T}_{8}:$ @ 8\% ginger extract in sucrose syrup & 7.30 & Like very much $(\mathrm{LVM})$ \\
\hline
\end{tabular}

Edible portion of fruit was found to contain 10 per cent TSS, 2.25 per cent acidity, 546.75 mg per $100 \mathrm{~g}$ fruit pulp ascorbic acid, 2.60 per cent reducing sugars, 2.23 per cent nonreducing sugar, 4.83 per cent total sugars and $160.56 \mathrm{mg}$ per $100 \mathrm{~g}$ of total phenols. Organoleptic evaluation was done to assess the quality of aonla candy made from different concentration of ginger extract for quality attributes such as appearance, flavor, consistency and overall acceptability of candy. The data recorded on overall ranking of sensory traits which were obtained by different concentration of ginger extract, the organoleptic quality of candy is given in table 3 . Result show that the candy prepared with $\mathrm{T}_{5}$ treatment was found to be the best followed by $\mathrm{T}_{4}$ and $\mathrm{T}_{6}$ treatment.

The organoleptic score of $\mathrm{T}_{5}$ treatment were rated as like extremely and rest of the treatment like very much by the panel of judges. The sensory quality factors that are very important for the aonla candy are colour, aroma, appearance and overall acceptability. Sample prepared with 5\% of ginger extract in sucrose syrup was like extremely much, however, treatment $\mathrm{T}_{5}$ (ginger extract @ 5\% in sucrose syrup) gave highest score, i.e. 8.40. Among several natural oil and extract ginger enriched aonla candy was found best by (Kumar and Pathak.2015). But literature related to concentration of ginger extract for preparation of aonla candy is lacking.

\section{References}

Amrine, M.A., Pangbron, R.M. and Rossler, E.B. (1965). Principal of Sensory Evaluation of Foods. Academic Press Inc., New York, USA

Gehlot, D. S. and Singh, R. (2008). Studies on physico-chemical composition and changes in bio-chemical constituents of aonla fruits cv. Chakaiya during processing into preserve. Haryana Journal of Horticultural Sciences; 37 (1/2): 43-44.

Kumar, R., and Pathak, S. (2015). Studies on ginger concentration for preparation of aonla candy. Haryana Journal of Horticultural Sciences; 32 (1/4): 109112.

Mandal, P., Sahoo, B. B., Das, B. C. and Katiyar, D. (2007). Studies on processing and storage stability of Aonla (Emblica officinalis Gaertn) Nectar. Hort. Flora Research Spectrum; 2 (3): 259- 261.

Pathak, S. (1988).Post-harvest technology of aonla (Emblica officinalis Gaertn.) fruits. Acta Hort., 204:172-174.

Rangana, S. (2010). Analysis and quality control for fruit and vegetable products. 
Tata McGraw Hill Ltd., New Delhi. Singh, I.S. and Pathak, R.K. (1987).Evaluation of aonla (Emblica

officinalis Garten.) Varieties for processing. Acta Hort., 208:173-177.

\section{How to cite this article:}

Gaurav Singh Vishen, Sanjay Pathak and Krishna Kumar Mishra. 2017. Studies on PhysicoChemical Composition of Aonla (Emblica officinalis G.) Fruit and Evaluation of Ginger Extract Concentration for Preparation of Aonla Candy Cv. Chakaiya. Int.J.Curr.Microbiol.App.Sci. 6(11): 3536-3540. doi: https://doi.org/10.20546/ijcmas.2017.611.414 